\title{
Identification of tumor antigens as potential target antigens for immunotherapy by serological expression cloning
}

Received: 12 September 2003 / Accepted: 24 October 2003/Published online: 15 January 2004

(C) Springer-Verlag 2004

\begin{abstract}
The presence of tumor infiltrating $\mathrm{T}$ cells has been shown to be associated with a favorable prognosis in different tumor types. Several strategies have been developed to identify relevant tumor antigens which can be used for active immunotherapy strategies. The SEREX technique (serological analysis of cDNA expression libraries) identifies tumor antigens based on a spontaneous humoral immune response in cancer patients. This technique is not limited to tumor types that can be grown in cell culture or depends on established $\mathrm{T}$ cell clones recognizing the autologous tumor. Several steps of analysis are mandatory to evaluate SEREXdefined antigens before they become new target antigens for active immunotherapy: expression analysis; serological analysis with sera from tumor patients and normal individuals; identification of potential peptide epitopes for CD8 T cells and evaluation in T cell assays. This article summarizes our approach of antigen identification and evaluation giving the example of the recently cloned breast cancer antigen NY-BR-1.
\end{abstract}

Keywords SEREX - CD8 T cell · Tumor antigen · Active immunotherapy

There is growing evidence that the immune system interacts with tumor cells during the natural course of the disease. Several investigators have demonstrated for different tumor types that the presence of tumor-infiltrating lymphocytes is associated with a better prognosis in individual patients $[1,2,3,4]$. These clinical observations suggest that tumor-infiltrating lymphocytes recognize specific antigens expressed by the tumor.

This work was presented at the first Cancer Immunology and Immunotherapy Summer School, 8-13 September 2003, Ionian Village, Bartholomeio, Peloponnese, Greece.

D. Jäger $(\bowtie) \cdot$ C. Taverna $\cdot$ A. Zippelius $\cdot$ A. Knuth

Klinik und Poliklinik für Onkologie, Universitätsspital Zurich, Rämistrasse 100, 8091 Zurich, Switzerland

E-mail: dirk.jaeger@usz.ch
Moreover, this immune response is somehow effective because it results in a better prognosis and prolonged survival of the individual patient. Several strategies have been developed to identify tumor antigens recognized by T cells: The T-cell epitope cloning technique developed by T. Boon's group [5] was successful in identifying tumor antigens based on their recognition by cytotoxic T cells (CTLs). The first cloned antigen by this technique was the melanoma antigen MAGE-1. Subsequently, new tumor antigens like those in the BAGE and GAGE gene family were identified following this cloning strategy $[6$, 7]. These antigens share some characteristic features: their expression in normal tissues is restricted to germ cells in the testis and the ovary, whereas these antigens are widely expressed in tumor tissues. Therefore, this group of antigens was recognized as a separate category, named "cancer-testis" antigens [8,9]. A different category of antigens comprises the differentiation antigens which are expressed in normal cells and tissues like melanocytes and their malignant counterpart, the melanoma. By using the same T-cell epitope cloning technique, Melan-A [10], tyrosinase [11], gp100 [12], and gp75 [13] were identified as T-cell-defined tumor antigens. Tumor-specific mutated antigens (CDK4, p53) can also be targets for cytotoxic $\mathrm{T}$ cells $[14,15]$. Mutated antigens represent individual antigens; the mutation is typically not shared by other individuals, with a few exceptions like the k-ras oncogene mutated in pancreatic cancer. Viral antigens are frequently expressed in certain cancers like cervical carcinoma and can be recognized by T lymphocytes [16].

A different antigen-discovery strategy analyzes peptide sequences which were eluted from MHC I complexes isolated from tumor cell lysates. By comparing the peptide sequence to databases, the relevant tumor antigen can be identified [17].

The identification of tumor antigens that elicited spontaneous $\mathrm{T}$-cell responses in cancer patients and the discovery of the mechanisms of antigen expression, processing, and MHC class I-restricted presentation of antigen-derived peptides made it possible to design 
peptide-based immunotherapy protocols. Patients with antigen-positive tumors were vaccinated with the relevant peptides that are naturally processed and presented in the context of the respective MHC I molecule [18]. It was shown in several phase I/II clinical studies that antigen-specific cellular immune responses (CD4 and CD8) can be induced by immunizing patients with the respective peptide $[19,20,21$, $22,23,24,25]$. In some patients, objective clinical remissions of single metastases and long-term clinical stabilizations were observed, whereas progression of antigen-negative lesions was frequently documented. This tumor escape phenomenon under antigen-specific immunotherapy reflects the development of clonal heterogeneity over time in most solid tumors. To circumvent the selection of antigen-negative tumor cell clones that have a proliferation advantage under the selection pressure of antigen-specific immunotherapy, polyvalent immunotherapy approaches targeting an array of tumor antigens at the same time are developed. To design such polyvalent immunotherapy strategies, it will be necessary to dissect the antigen expression profile of a given tumor.

The development of a new cloning technique called SEREX (serological expression cloning) [26] to identify tumor antigens, based on a spontaneous humoral immune response in the cancer patient, made it possible to analyze tumor systems independent of the need to grow them in cell culture. Furthermore, the SEREX technique does not rely on $\mathrm{T}$ cell lines that recognize the autologous tumor [27]. It was shown for the SEREX-defined antigen NY-ESO-1 that spontaneous CD8 T-cell responses correlate to a high percentage with a humoral immune response in patients with NY-ESO-1-positive tumors. Dissecting the humoral immune response against tumor antigens defines the CD4 T-cell antigen repertoire of an individual patient. These antigens can potentially be recognized by CD8 $\mathrm{T}$ cells $[21,28]$. The SEREX technique was applied to different tumor types which led to the identification of HOM-MEL-40, a gene identical to the synovial sarcoma/X breakpoint 2 gene (SSX2) involved in the $\mathrm{t}(\mathrm{x}: 18)$ translocation in synovial sarcoma [29], as well as other cancer-testis (CT) antigens including NY-ESO-1 [30], CT7/MAGE-C1 [31], SCP-1 [32], OY-TES-1 [34], HOM-TES-85 [35], CAGE [36], cTAGE [33], and recently NY-SAR-35 [37]. Besides the new CT antigens, we were successful with the SEREX technique in identifying several new differentiation antigens like Rab38 [38] and NY-BR-1 [39], as well as overexpressed antigens like tumor protein D52, NY-BR62 or NY-BR-85. SEREX represents a useful screening technique to define the individual CD4 T-cell tumorantigen repertoire. Today, more than 1,000 antigens have been identified by SEREX and deposited in the SEREX database of the Ludwig Institute for Cancer Research (http://www.licr.org/SEREX.html).

Several steps of analysis are required before it is established that SEREX-defined antigens become potential target antigens for active immunotherapy trials in cancer patients:

In the first step, a careful expression analysis for each antigen has to be performed by comparing the cDNA sequence to EST databases. Antigens with restricted expression by database analysis are being tested by RTPCR using a panel of normal tissue and tumor tissue cDNAs to confirm the restricted mRNA expression pattern.

Antigens that show a tumor/tissue-restricted expression pattern undergo a serological analysis to define the frequency of humoral immune responses in sera derived from cancer patients and normal individuals. A limited number of sera can be tested using the phage-plaque assay; for large-scale serology, the recombinant protein has to be produced and tested in Western blot assays.

Antigens with tumor/tissue-specific expression and detectable humoral immune responses in tumor patients are analyzed for T-cell recognition. We follow an approach called the "reverse immunology approach" where we test the entire protein sequence of the respective antigen for potential MHC class I-binding sequences (see CancerImmunomeDB, SYFPEITHI database of MHC ligands and peptide motifs at http:// www.bmi-heidelberg.com/syfpeithi/). We focus primarily on HLA-A2 epitopes because HLA-A2 represents the most frequent MHC class I allele in the Western European population. Peptide-specific CTLs can be generated upon in vitro stimulation, and recognition of target cells expressing the antigenic protein will be documented. Finally, CD8 T-cell reactivity to the identified epitope can be analyzed in peripheral blood and tumor lesions of a large series of HLA-A2-positive patients with antigen-positive tumors.

Tumor antigens that fall in the categories of CT antigens or differentiation antigens which represent target antigens for CD8 T cells can be used to immunize HLA-A2-positive patients with antigen-positive tumors. The petides that are recognized by CD $8 \mathrm{~T}$ cells will be used for intradermal injection. The readout includes DTH reaction, induction of peptide-specific CD8 T cells (ELISPOT, Multimer), and clinical evolution of the disease. The following list summarizes the steps of analyzing SEREX-defined antigens as potential targets for CD8 T cells:

- SEREX analysis

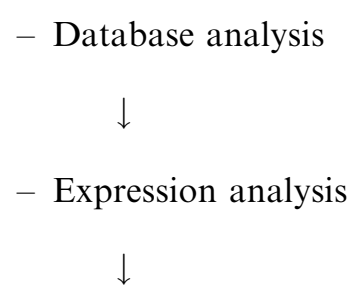

- Database analysis

- Expression analysis

$\downarrow$ 
- Serology

$\downarrow$

- MHC-motif search for epitopes

$\downarrow$

- ELISPOT assays (T-cell reactivity)

$\downarrow$

\section{- Immunotherapy trial}

These different steps of analysis are illustrated in a recent SEREX analysis performed by our group. In an autologous SEREX screening of a breast cancer cDNA expression library we identified a previously unknown antigen designated as NY-BR-1. About half of the clones identified in the screening were derived from NYBR-1, while the other clones were derived from distinct known and unknown genes. Comparison with EST databases showed only some cDNA sequences matching the NY-BR-1 cDNA. Interestingly, some sequences were derived from testis, one sequence was derived from normal breast. All other antigens identified in this screening matched to cDNA sequences derived from a wide array of normal tissues and were not further analyzed.

Following a combined approach of RACE-PCR and database analysis for overlapping cDNA sequences to complete the $5^{6}$-cDNA sequence, we were able to clone the full length NY-BR-1 cDNA which is approximately $6 \mathrm{~kb}$, coding for a protein of approximately $160 \mathrm{kDA}$. RT-PCR analysis in a normal tissue panel using NYBR-1-specific primers showed NY-BR-1 mRNA to be exclusively expressed in normal breast and normal testis, and variable in normal prostate. In tumor tisues, NYBR-1 is expressed in $70-80 \%$ of breast cancers, $25 \%$ of prostate cancers, while all other tumor types are NYBR-1-negative [39].

Based on the expression analysis, NY-BR-1 represents a new member of the group of differentiation antigens. We produced a short carboxyl-terminal recombinant protein for larger scale serological analysis and found humoral immune responses in approximately $10 \%$ of patients with NY-BR-1-positive breast cancers. Importantly, all normal sera were tested negative. To further elucidate $\mathrm{T}$-cell responses against NY-BR-1, the entire NY-BR-1 protein sequence was screened for potential HLA-A2-binding motifs. Indeed, numerous potentially binding peptides were synthesized. CD8 T cells derived from PBMCs of the seropositive HLA-A2-positive breast cancer patient were stimulated once with each of the peptides and then tested in an ELISPOT assay for specific recognition. We could identify some peptides that were specifically recognized by CD8 $\mathrm{T}$ cells. We could further demonstrate that those peptides represent naturally processed and presented NY-BR-1 epitopes (D. Jäger et al., unpublished data).

In summary, we (1) discovered a new tumor antigen by applying the SEREX technology, (2) demonstrated a tumor-specific expression pattern, and (3) identified NY-BR-1-derived peptide epitopes that are naturally processed and presented to CD8 T cells. A phase I clinical trial for HLA-A2-positive patients with advanced NY-BR-1-expressing breast cancer or prostate cancer is under way. Vaccination with the two NY-BR1-derived peptides will show if potent antigen-specific CD8 T-cell responses can be induced. Clinical effects and potential side effects in normal breast tissue will be carefully analyzed.

As illustrated with this example, but demonstrated previously for other antigens such as NY-ESO-1, the identification of new tumor antigens by SEREX technology is essential to broaden the spectrum of target antigens, a prerequisite for making future cancer vaccines more efficient.

\section{References}

1. Naito Y, Saito K, Shiiba K, Ohuchi A, Saigenji K, Nagura H, Ohtani H (1998) CD8 + T cells infiltrated within cancer cell nests as a prognostic factor in human colorectal cancer. Cancer Res 58:3491-3494

2. Nakano O, Sato M, Naito Y, Suzuki K, Orikasa S, Aizawa M, Suzuki Y, Shintaku I, Nagura H, Ohtani H (2001) Proliferative activity of intratumoral CD8(+) T-lymphocytes as a prognostic factor in human renal cell carcinoma: clinicopathologic demonstration of antitumor immunity. Cancer Res 61:5132-5136

3. Schumacher K, Haensch W, Roefzaad C, Schlag PM (2001) Prognostic significance of activated CD8 $(+) \mathrm{T}$ cell infiltrations within esophageal carcinomas. Cancer Res 61:3932-3936

4. Eerola AK, Soini Y, Paakko P (2000) A high number of tumorinfiltrating lymphocytes are associated with a small tumor size, low tumor stage, and a favorable prognosis in operated small cell lung carcinoma. Clin Cancer Res 6:1875-1881

5. van der Bruggen $\mathrm{P}$, Traversari $\mathrm{C}$, Chomez $\mathrm{P}$, Lurquin $\mathrm{C}, \mathrm{De}$ Plaen E, Van den Eynde B, Knuth A, Boon T (1991) A gene encoding an antigen recognized by cytolytic $\mathrm{T}$ lymphocytes on a human melanoma. Science 254:1643-1647

6. Boel P, Wildmann C, Sensi ML, Brasseur R, Renauld JC, Coulie P, Boon T, van der Bruggen P (1995) BAGE: a new gene encoding an antigen recognized on human melanomas by cytolytic T lymphocytes. Immunity $2: 167-175$

7. Van den Eynde B, Peeters O, De Backer O, Gaugler B, Lucas S, Boon T (1995) A new family of genes coding for an antigen recognized by autologous cytolytic $\mathrm{T}$ lymphocytes on a human melanoma. J Exp Med 182:689-698

8. Boon T, van der Bruggen P (1996) Human tumor antigens recognized by T lymphocytes. J Exp Med 183:725-729

9. Scanlan MJ, Gure AO, Jungbluth AA, Old LJ, Chen YT (2002) Cancer/testis antigens: an expanding family of targets for cancer immunotherapy. Immunol Rev 188:22-32

10. Coulie PG, Brichard V, Van Pel A, Wolfel T, Schneider J, Traversari C, Mattei S, De Plaen E, Lurquin C, Szikora JP et al (1994) A new gene coding for a differentiation antigen recognized by autologous cytolytic $\mathrm{T}$ lymphocytes on HLA-A2 melanomas [see comments]. J Exp Med 180:35-42

11. Brichard V, Van Pel A, Wolfel T, Wolfel C, De Plaen E, Lethe B, Coulie P, Boon T (1993) The tyrosinase gene codes for an antigen recognized by autologous cytolytic $\mathrm{T}$ lymphocytes on HLA-A2 melanomas. J Exp Med 178:489-495 
12. Kawakami Y, Eliyahu S, Delgado CH, Robbins PF, Sakaguchi K, Appella E, Yannelli JR, Adema GJ, Miki T, Rosenberg SA (1994) Identification of a human melanoma antigen recognized by tumor- infiltrating lymphocytes associated with in vivo tumor rejection. Proc Natl Acad Sci U S A 91:6458-6462

13. Wang RF, Robbins PF, Kawakami Y, Kang XQ, Rosenberg SA (1995) Identification of a gene encoding a melanoma tumor antigen recognized by HLA-A31-restricted tumor-infiltrating lymphocytes [published erratum appears in J Exp Med (1995) 181(3):1261]. J Exp Med 181:799-804

14. Wolfel T, Hauer M, Schneider J, Serrano M, Wolfel C, Klehmann-Hieb E, De Plaen E, Hankeln T, Meyer zum Buschenfelde KH, Beach D (1995) A p16INK4a-insensitive CDK4 mutant targeted by cytolytic $\mathrm{T}$ lymphocytes in a human melanoma. Science 269:1281-1284

15. Gnjatic S, Cai Z, Viguier M, Chouaib S, Guillet JG, Choppin J (1998) Accumulation of the p53 protein allows recognition by human CTL of a wild-type p53 epitope presented by breast carcinomas and melanomas. J Immunol 160:328-333

16. Jochmus I, Osen W, Altmann A, Buck G, Hofmann B, Schneider A, Gissmann L, Rammensee HG (1997) Specificity of human cytotoxic $\mathrm{T}$ lymphocytes induced by a human papillomavirus type 16 E7-derived peptide. J Gen Virol 78(7):1689-1695

17. Rammensee HG, Weinschenk T, Gouttefangeas C, Stevanovic S (2002) Towards patient-specific tumor antigen selection for vaccination. Immunol Rev 188:164-176

18. Jager E, Jager D, Knuth A (2002) Clinical cancer vaccine trials. Curr Opin Immunol 14:178-182

19. Jager E, Nagata Y, Gnjatic S, Wada H, Stockert E, Karbach J, Dunbar PR, Lee SY, Jungbluth A, Jager D, Arand M, Ritter G, Cerundolo V, Dupont B, Chen YT, Old LJ, Knuth A (2000) Monitoring CD8 T cell responses to NY-ESO-1: correlation of humoral and cellular immune responses. Proc Natl Acad Sci U S A 97:4760-4765

20. Jaeger E, Bernhard H, Romero P, Ringhoffer M, Arand M, Karbach J, Ilsemann C, Hagedorn M, Knuth A (1996) Generation of cytotoxic T-cell responses with synthetic melanomaassociated peptides in vivo: implications for tumor vaccines with melanoma-associated antigens. Int J Cancer 66:162-169

21. Jager E, Chen YT, Drijfhout JW, Karbach J, Ringhoffer M, Jager D, Arand M, Wada H, Noguchi Y, Stockert E, Old LJ, Knuth A (1998) Simultaneous humoral and cellular immune response against cancer-testis antigen NY-ESO-1: definition of human histocompatibility leukocyte antigen (HLA)-A2-binding peptide epitopes. J Exp Med 187:265-270

22. Jager E, Gnjatic S, Nagata Y, Stockert E, Jager D, Karbach J, Neumann A, Rieckenberg J, Chen YT, Ritter G, Hoffman E, Arand M, Old LJ, Knuth A (2000) Induction of primary NYESO-1 immunity: CD8 + T lymphocyte and antibody responses in peptide-vaccinated patients with NY-ESO-1 + cancers. Proc Natl Acad Sci U S A 97:12198-12203

23. Jager E, Ringhoffer M, Dienes HP, Arand M, Karbach J, Jager D, Ilsemann C, Hagedorn M, Oesch F, Knuth A (1996) Granulocyte-macrophage-colony-stimulating factor enhances immune responses to melanoma-associated peptides in vivo. Int J Cancer 67:54-62

24. Rosenberg SA, Yang JC, Schwartzentruber DJ, Hwu P, Marincola FM, Topalian SL, Restifo NP, Dudley ME, Schwarz SL, Spiess PJ, Wunderlich JR, Parkhurst MR, Kawakami Y, Seipp CA, Einhorn JH, White DE (1998) Immunologic and therapeutic evaluation of a synthetic peptide vaccine for the treatment of patients with metastatic melanoma [see comments]. Nat Med 4:321-327

25. Marchand M, van Baren N, Weynants P, Brichard V, Dreno B, Tessier MH, Rankin E, Parmiani G, Arienti F, Humblet Y, Bourlond A, Vanwijck R, Lienard D, Beauduin M, Dietrich PY, Russo V, Kerger J, Masucci G, Jager E, De Greve J, Atzpodien J, Brasseur F, Coulie PG, van der Bruggen P,
Boon T (1999) Tumor regressions observed in patients with metastatic melanoma treated with an antigenic peptide encoded by gene MAGE-3 and presented by HLA-A1. Int J Cancer 80:219-230

26. Sahin U, Tureci O, Schmitt H, Cochlovius B, Johannes T, Schmits R, Stenner F, Luo G, Schobert I, Pfreundschuh M (1995) Human neoplasms elicit multiple specific immune responses in the autologous host. Proc Natl Acad Sci U S A 92:11810-11813

27. Scanlan MJ, Gout I, Gordon CM, Williamson B, Stockert E, Gure AO, Jäger D, Chen Y-T, Mackay A, O'Hare MJ, Old LJ (2001) Humoral immunity to human breast cancer: antigen definition and quantitative analysis of mRNA expression. Cancer Immun 1:4

28. Ayyoub M, Stevanovic S, Sahin U, Guillaume P, Servis C, Rimoldi D, Valmori D, Romero P, Cerottini JC, Rammensee HG, Pfreundschuh M, Speiser D, Levy F (2002) Proteasomeassisted identification of a SSX-2-derived epitope recognized by tumor-reactive CTL infiltrating metastatic melanoma J Immunol 168:1717-1722

29. Tureci O, Chen YT, Sahin U, Gure AO, Zwick C, Villena C, Tsang S, Seitz G, Old LJ, Pfreundschuh M (1998) Expression of SSX genes in human tumors. Int J Cancer 77:19-23

30. Chen YT, Scanlan MJ, Sahin U, Tureci O, Gure AO, Tsang S, Williamson B, Stockert E, Pfreundschuh M, Old LJ (1997) A testicular antigen aberrantly expressed in human cancers detected by autologous antibody screening. Proc Natl Acad Sci U S A 94:1914-1918

31. Chen YT, Gure AO, Tsang S, Stockert E, Jager E, Knuth A, Old LJ (1998) Identification of multiple cancer/testis antigens by allogeneic antibody screening of a melanoma cell line library. Proc Natl Acad Sci U S A 95:6919-6923

32. Tureci O, Sahin U, Zwick C, Koslowski M, Seitz G, Pfreundschuh M (1998) Identification of a meiosis-specific protein as a member of the class of cancer/testis antigens. Proc Natl Acad Sci U S A 95:5211-5216

33. Eichmuller S, Usener D, Dummer R, Stein A, Thiel D, Schadendorf D (2001) Serological detection of cutaneous T-cell lymphoma-associated antigens. Proc Natl Acad Sci U S A 98:629-634

34. Ono T, Kurashige T, Harada N, Noguchi Y, Saika T, Niikawa N, Aoe M, Nakamura S, Higashi T, Hiraki A, Wada H, Kumon H, Old LJ, Nakayama E (2001) Identification of proacrosin binding protein sp32 precursor as a human cancer/testis antigen. Proc Natl Acad Sci U S A 98:3282-3287

35. Tureci O, Sahin U, Koslowski M, Buss B, Bell C, Ballweber P, Zwick C, Eberle T, Zuber M, Villena-Heinsen C, Seitz G, Pfreundschuh M (2002) A novel tumour associated leucine zipper protein targeting to sites of gene transcription and splicing. Oncogene 21:3879-3888

36. Cho B, Lim Y, Lee DY, Park SY, Lee H, Kim WH, Yang H, Bang YJ, Jeoung DI (2002) Identification and characterization of a novel cancer/testis antigen gene CAGE. Biochem Biophys Res Commun 292:715-726

37. Lee SY, Obata Y, Yoshida M, Stockert E, Williamson B, Jungbluth AA, Chen YT, Old LJ, Scanlan MJ (2003) Immunomic analysis of human sarcoma. Proc Natl Acad Sci U S A 100:2651-2656

38. Jager D, Stockert E, Jager E, Gure AO, Scanlan MJ, Knuth A, Old LJ, Chen YT (2000) Serological cloning of a melanocyte rab guanosine 5'-triphosphate-binding protein and a chromosome condensation protein from a melanoma complementary DNA library. Cancer Res 60:3584-3591

39. Jager D, Stockert E, Gure AO, Scanlan MJ, Karbach J, Jager E, Knuth A, Old LJ, Chen YT (2001) Identification of a tissuespecific putative transcription factor in breast tissue by serological screening of a breast cancer library. Cancer Res 61:2055-2061 